\title{
Article
}

\section{Feasibility of Rapid Diagnostic Technology for SARS-CoV-2 Virus Using a Trace Amount of Saliva}

\author{
Reiko Tokuyama-Toda ${ }^{1}{ }^{\oplus}$, Masaaki Muraoka ${ }^{2}{ }^{\oplus}$, Chika Terada-Ito $^{1}$, Shinji Ide ${ }^{1}$, Toshikatsu Horiuchi ${ }^{3}$, \\ Tsuyoshi Amemiya ${ }^{3}$, Airi Fukuoka ${ }^{3}$, Yoshiki Hamada ${ }^{4}$, Shunsuke Sejima ${ }^{2}$ and Kazuhito Satomura ${ }^{1, * \mathbb{C}}$ \\ 1 Department of Oral Medicine and Stomatology, School of Dental Medicine, Tsurumi University, 2-1-3, \\ Tsurumi, Tsurumi-ku, Yokohama City 230-8501, Japan; tokuyama-r@tsurumi-u.ac.jp (R.T.-T.); \\ terada-chika@tsurumi-u.ac.jp (C.T.-I.); ide-shinji@tsurumi-u.ac.jp (S.I.) \\ 2 Certified Non-Profit Organization Biomedical Science Association, 2-20-8, Kamiosaki, Shinagawa-ku, \\ Tokyo 141-0021, Japan; yosami.muraoka@gmail.com (M.M.); sejima@npo-bmsa.org (S.S.) \\ 3 Department of Oral and Maxillofacial Surgery, Saiseikai Yokohamashi Tobu Hospital, 3-6-1, Shimosueyoshi, \\ Tsurumi-ku, Yokohama City 230-8765, Japan; t_horiuchi@tobu.saiseikai.or.jp (T.H.); \\ t_amemiya@tobu.saiseikai.or.jp (T.A.); a_fukuoka@tobu.saiseikai.or.jp (A.F.) \\ 4 Department of Oral and Maxillofacial Surgery, School of Dental Medicine, Tsurumi University, 2-1-3, Tsurumi, \\ Tsurumi-ku, Yokohama City 230-8501, Japan; hamada-y@tsurumi-u.ac.jp \\ * Correspondence: satomura-k@tsurumi-u.ac.jp
}

check for updates

Citation: Tokuyama-Toda, R.; Muraoka, M.; Terada-Ito, C.; Ide, S.; Horiuchi, T.; Amemiya, T.; Fukuoka, A.; Hamada, Y.; Sejima, S.; Satomura, K. Feasibility of Rapid Diagnostic Technology for SARS-CoV-2 Virus Using a Trace Amount of Saliva. Diagnostics 2021, 11, 2024. https:/ / doi.org/10.3390/diagnostics11112024

Academic Editor: Anna Baraniak

Received: 7 October 2021

Accepted: 29 October 2021

Published: 1 November 2021

Publisher's Note: MDPI stays neutral with regard to jurisdictional claims in published maps and institutional affiliations.

Copyright: (C) 2021 by the authors. Licensee MDPI, Basel, Switzerland. This article is an open access article distributed under the terms and conditions of the Creative Commons Attribution (CC BY) license (https:// creativecommons.org/licenses/by/ $4.0 /)$.

\begin{abstract}
Containment of SARS-CoV-2 has become an urgent global issue. To overcome the problems of conventional quantitative polymerase chain reaction (qPCR) tests, we verified the usefulness of a mobile qPCR device that utilizes mouthwash to obtain a saliva sample with the aim of developing a rapid diagnostic method for SARS-CoV-2. First, we examined whether anyone could easily operate this device. Then, we examined whether RNA in the mouthwash could be detected in a short time. In addition, we investigated whether it was possible to diagnose SARS-CoV-2 infection using mouthwash obtained from COVID-19 patients undergoing hospitalization. The results revealed that all subjects were able to complete the operation properly without error. In addition, RNase P was detected in the mouthwash without pretreatment. The average detection time was $18 \mathrm{~min}$, which is significantly shorter than conventional qPCR devices. Furthermore, this device detected SARS-CoV-2 in the mouthwash of a COVID-19 patient undergoing hospitalization. The above findings verified the efficacy of this diagnostic method, which had a low risk of infection, was technically simple, and provided stable results. Therefore, this method is useful for the rapid detection of SARS-CoV-2.
\end{abstract}

Keywords: COVID-19; SARS-CoV-2; mobile qPCR device; mouthwash; saliva

\section{Introduction}

COVID-19, which is caused by the SARS-CoV-2 virus, was first discovered in 2019, and has emerged as a worldwide pandemic; therefore, its containment has become a serious and urgent global issue. For the definitive diagnosis of SARS-CoV-2 infection, detection of viral RNA by quantitative polymerase chain reaction (qPCR) is currently the most reliable and widely used method [1-3]. However, since the qPCR test must be performed by a skilled specialist or clinical laboratory technician, securing qPCR test equipment and skilled human resources to perform the GPCR test is an important practical issue. In addition, the long turnaround time of the current qPCR test is also a problem. These negative characteristics are associated with a decreased demand for these kinds of tests [4]. Furthermore, an adequate number of skilled human resources are needed to perform the specialized techniques, such as nasal swabs, that are required for sample collection. Therefore, a necessary step toward effective containment of COVID-19 is to expand qPCR testing for SARS-CoV-2 that entails securing skilled technicians who can perform qPCR tests and operate qPCR test equipment. Aligned with these objectives is the development 
of a new qPCR test method that can obtain diagnostic results in a much shorter time using samples that can be collected more easily and safely by anyone, including the tested person.

Recently, a small, portable mobile qPCR device (PCR1100, Nippon Sheet Glass Co., Ltd., Tokyo, Japan) was developed for research purposes (Supplementary Materials). PCR1100 is compact and lightweight with a main body size of $\mathrm{H} 200 \times \mathrm{W} 100 \times \mathrm{D} 50 \mathrm{~mm}$ and a weight of approximately $560 \mathrm{~g}$. It obtains accurate measurements within $10 \mathrm{~min}$ by qPCR. These results indicate that the time required for qPCR testing in clinical practice can be significantly reduced. PCR1100 successfully detected the presence of each target microorganism in food hygiene tests for Salmonella, Campylobacter, and Escherichia coli O-157, and in environmental bacteria tests for Legionella. If these detection capabilities could be achieved by a device that can be operated easily by the user, such as performing rapid detection of pathogens from saliva samples without pretreatment, then this device can be applied as a point-of-care testing (POCT) device for COVID-19 diagnosis. Furthermore, a POCT device would enable earlier diagnosis of SARS-CoV-2 infection compared to conventional qPCR methods.

Therefore, in this study, we examined whether this device could be adapted for the medical field and whether saliva samples could be used with this device for rapid diagnosis. To prove whether rapid diagnosis of SARS-CoV-2 is possible, synthetic RNA was used to confirm the diagnosis. Furthermore, we investigated whether SARS-CoV-2 viral RNA could be detected by this device using samples from COVID-19 patients who had been diagnosed as SARS-CoV-2 positive via the conventional qPCR method.

\section{Materials and Methods}

\subsection{Sample}

Positive control RNA samples of SARS-CoV-2 developed following the National Institute of Infectious Diseases (NIID) protocol were kindly provided by the NIID (for N primer probe Ver.2 and N2 primer probe Ver.2/Ver.3). Following the Centers for Disease Control and Prevention (CDC) protocol, RNA samples were synthesized by FASMAC Co., Ltd., (Atsugi, Kanagawa, Japan) based on each primer sequence and information obtained from GenBank ${ }^{\mathrm{TM}}$ : accession number MN997409.1, position -10/+110 for 2019-nCoV_N1 and position $+871 /+980$ for_N2. RNase P were similarly synthesized; accession number U77665.1, position $+21 /+130$. Applied to each positive control, RNA was 10 -fold serially diluted with $10 \mathrm{mM}$ Tris- $\mathrm{HCl}$ (pH 8.0, molecular grade) including $10 \mu \mathrm{g} / \mathrm{mL}$ carrier RNA (ribonucleic acid from baker's yeast, Merck KGaA, Darmstadt, Germany).

\subsection{Primer and Probe}

Based on previously reported protocols for SARS-CoV-2 (CDC 2020 protocol [5]), oligonucleotide primers and probes for quantitative reverse transcriptase polymerase chain reaction (qRT-PCR) detection were selected to target each $\mathrm{N}$ gene and were then synthesized by Nihon Gene Research Laboratories Inc. (Sendai, Japan) (Table 1). Based on the CDC protocol (CDC 2020), oligonucleotide primers and probes to detect human RNase $P$ were also synthesized.

Table 1. PCR primers/probes and control RNA sequence.

\begin{tabular}{|c|c|c|c|c|}
\hline \multicolumn{2}{|c|}{ Target Name } & Sequence & $\begin{array}{c}\begin{array}{c}\text { Final Con- } \\
\text { centration }\end{array} \\
0.40 \mu \mathrm{M}\end{array}$ & Amplicon \\
\hline hRNase P & $\begin{array}{l}\text { forward } \\
\text { reverse } \\
\text { probe }\end{array}$ & $\begin{array}{l}5^{\prime} \text {-AGA TTT GGA CCT GCG AGC G-3' } \\
5^{\prime} \text {-GAG CGG CTG TCT CCA CAA GT-3' } \\
5^{\prime} \text {-FAM-TTC TGA CCT GAA GGC TCT GCG CG-BHQ1-3' }\end{array}$ & $\begin{array}{l}0.40 \mu \mathrm{M} \\
0.40 \mu \mathrm{M} \\
0.20 \mu \mathrm{M}\end{array}$ & $65 \mathrm{bp}$ \\
\hline $\begin{array}{l}\text { 2019-nCoV_Nl } \\
\text { (CDC N1) }\end{array}$ & forward reverse probe & $\begin{array}{l}5^{\prime} \text {-GAC CCC AAA ATC AGC GAA AT-3' } \\
5^{\prime} \text {-TCT GGT TAC TGC CAG TTG AAT CTG-3' } \\
5^{\prime} \text {-HEX-ACC CCG CAT TAC GTT TGG TGG ACC-BHQ1-3' }\end{array}$ & $\begin{array}{l}0.20 \mu \mathrm{M} \\
0.20 \mu \mathrm{M} \\
0.20 \mu \mathrm{M}\end{array}$ & $72 \mathrm{bp}$ \\
\hline
\end{tabular}


focusing on the application of the sample to the flow path chip and determining the ease of handling of the device. The examinees were first given a brief explanation of how to handle the pipette. Then, $1 \mu \mathrm{L}$ of the sample was mixed with the premix to prepare a reaction solution, and $16.5 \mu \mathrm{L}$ of the reaction solution was collected and applied to the flow path chip. A pre-set reaction program was selected; the flow path chip was placed in a predefined position; and the reaction was initiated. Then, it was verified whether the device operated normally (Figure 1).

Table 2. The subjects' occupation and age.

\begin{tabular}{ccc}
\hline Number & Occupation & Age \\
\hline 1 & Dental hygienist & 43 \\
2 & Dental hygienist & 26 \\
3 & Dental hygienist & 29 \\
4 & Nurse & 47 \\
5 & Dental hygienist & 36 \\
6 & Nurse & 53 \\
7 & Dental hygienist & 37 \\
8 & Nurse & 45 \\
9 & Nurse & 49 \\
10 & Nurse & 44 \\
\hline
\end{tabular}

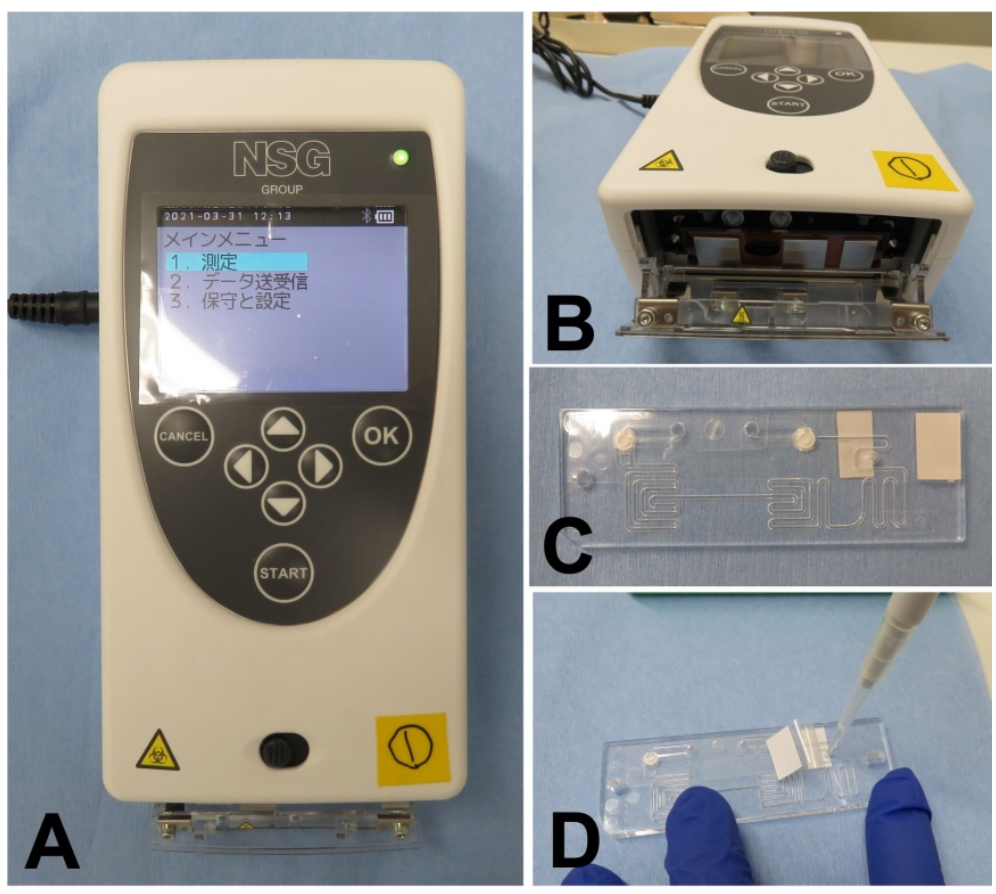

Figure 1. PCR1100 device body and flow path chip: (A) PCR1100 body (top). (B) Bottom (opening). Three heat blocks were provided. (C) Flow path chip. The sample moved in the flow path, the temperature was controlled by three heat blocks, and the PCR reaction proceeded. (D) The sample was injected into the hole of the flow path tip.

\subsection{Possible Usage of a Trace Amount of Saliva without Pretreatment as a Sample}

Verification was conducted under the approval of the Ethics Review Committee of the Faculty of Dentistry, Tsurumi University, Japan (No. 1841). The purpose of this examination was to investigate whether it was possible to prepare saliva without pretreatment of the sample for qPCR performed by this device. First, saliva was collected from healthy volunteers, and $1 \mu \mathrm{L}$ of the undiluted solution and the 2 -fold diluted solution were used as samples to examine whether the mixed RNase P synthetic RNA could be detected. In 
addition, it was also examined whether saliva could be used universally as a sample by mixing the saliva of five volunteers to produce a representative saliva.

In this study, we investigated whether it was possible to detect RNase P originally contained in saliva without mixing synthetic RNA into the sample saliva. Saliva collected from volunteers was diluted 2-fold and 4-fold with phosphate-buffered saline (PBS), of which $1 \mu \mathrm{L}$ was used as a sample to examine whether RNase P could be detected by the PCR1100.

\subsection{Possible Usage of Mouthwash as a Sample Instead of Saliva}

In this study, we investigated whether it was possible to use mouthwash as a sample, as it would be easier to collect a sample of mouthwash than a sample of saliva itself. To collect the sample, after gargling the mouth thoroughly with 1 or $2 \mathrm{~mL}$ of diluted PBS or saline for 10 or $15 \mathrm{~s}$, mouthwash was spat out into a clean tube. We investigated whether RNase P could be detected using $3 \mu \mathrm{L}$ of this mouthwash. In addition, $3 \mu \mathrm{L}$ of the mouthwash produced from washing the mouth with $2 \mathrm{~mL}$ of physiological saline for $15 \mathrm{~s}$ was examined as a sample. Furthermore, since it may not be possible to use the collected sample immediately for qPCR testing in clinical practice, we decided to confirm whether endogenous RNA could be detected even when the mouthwash had been stored frozen for 2 weeks.

\subsection{Influence of Sample Collection Conditions on qRT-PCR}

The timing of collecting mouthwash was also examined. It was investigated whether it was possible to collect mouthwash under three conditions: normal conditions of $\sim 3 \mathrm{~h}$ after eating and brushing teeth, $30 \mathrm{~min}$ after lightly washing the mouth after eating, and $15 \mathrm{~min}$ after brushing teeth, and we used these as samples.

\subsection{Detection of SARS-CoV-2 Synthetic RNA in Mouthwash Sample}

Next, we investigated whether SARS-CoV-2 RNA could be detected using the PCR1100. Synthesized SARS-CoV-2 RNA was mixed with the mouthwash collected under the three test conditions, and it was examined whether it could be detected by the PCR1100. A premix solution was prepared by mixing the two qPCR primers and probes used for SARS-CoV-2 detection according to the CDC protocol (2019-nCoV_N1, 2019-nCoV_N2) (Table 1) and the qRT-PCR reagent $(20 \mu \mathrm{L})$. Then, we mixed $3 \mu \mathrm{L}$ of mouthwash containing SARS-CoV-2 synthetic RNA with the premix and performed qPCR to examine whether SARS-CoV-2 RNA could be detected by the PCR1100. In addition, to prevent degradation of RNA by saliva, a sample in which synthetic RNA was first mixed with premix was also verified.

\subsection{Detection of SARS-CoV-2 Viral RNA in Mouthwash Obtained from COVID-19 Patients}

Finally, we investigated whether this diagnostic method could be used to detect COVID-19 in patients who had been diagnosed as SARS-CoV-2 positive by the conventional qPCR test. Using the mouthwash of a COVID-19 patient as a sample, we investigated whether SARS-CoV-2 RNA could be detected with this device. This verification was conducted under the approval of the Tsurumi University School of Dentistry Ethics Review Committee (No. 121002) and the Saiseikai Yokohamashi Tobu Hospital Ethics Review Committee (No. 20210012). Among patients admitted to Saiseikai Yokohamashi Tobu Hospital under the diagnosis of COVID-19, 20 adult men and women consented to participate in this study. After admission with a COVID-19 diagnosis based on conventional qPCR testing, an initial PCR1100 test was performed, followed by several additional PCR1100 tests to evaluate progression. We investigated whether the PCR1100 test could detect SARS-CoV-2 viral RNA contained in mouthwash. In addition, we investigated whether SARS-CoV-2 viral RNA detected by several PCR1100 tests during hospitalization was correlated with the individual symptom course, recovery status, and during the period after onset of symptoms. 


\section{Results}

\subsection{Analytical Limits of Detection (LoD)}

We developed a multichannel system that could fully detect the targets of the CDC protocol. As shown in Figure 2, in each of RNase P, SARS-CoV-2 CDC N1, and SARS-CoV-2 CDC N2, there was a high correlation between the concentration of synthetic RNA and the $\mathrm{Ct}$ value. The limits of detection (LoD) were 10 copies for RNase P and SARS-CoV-2 CDC N1 but 10,000 copies for SARS-CoV-2 CDC N2. Although it may be possible to set more appropriate conditions in a multi-channel system, even in the present system, multi-channel detection using PCR 1100 clearly showed a sufficiently high sensitivity and specificity.
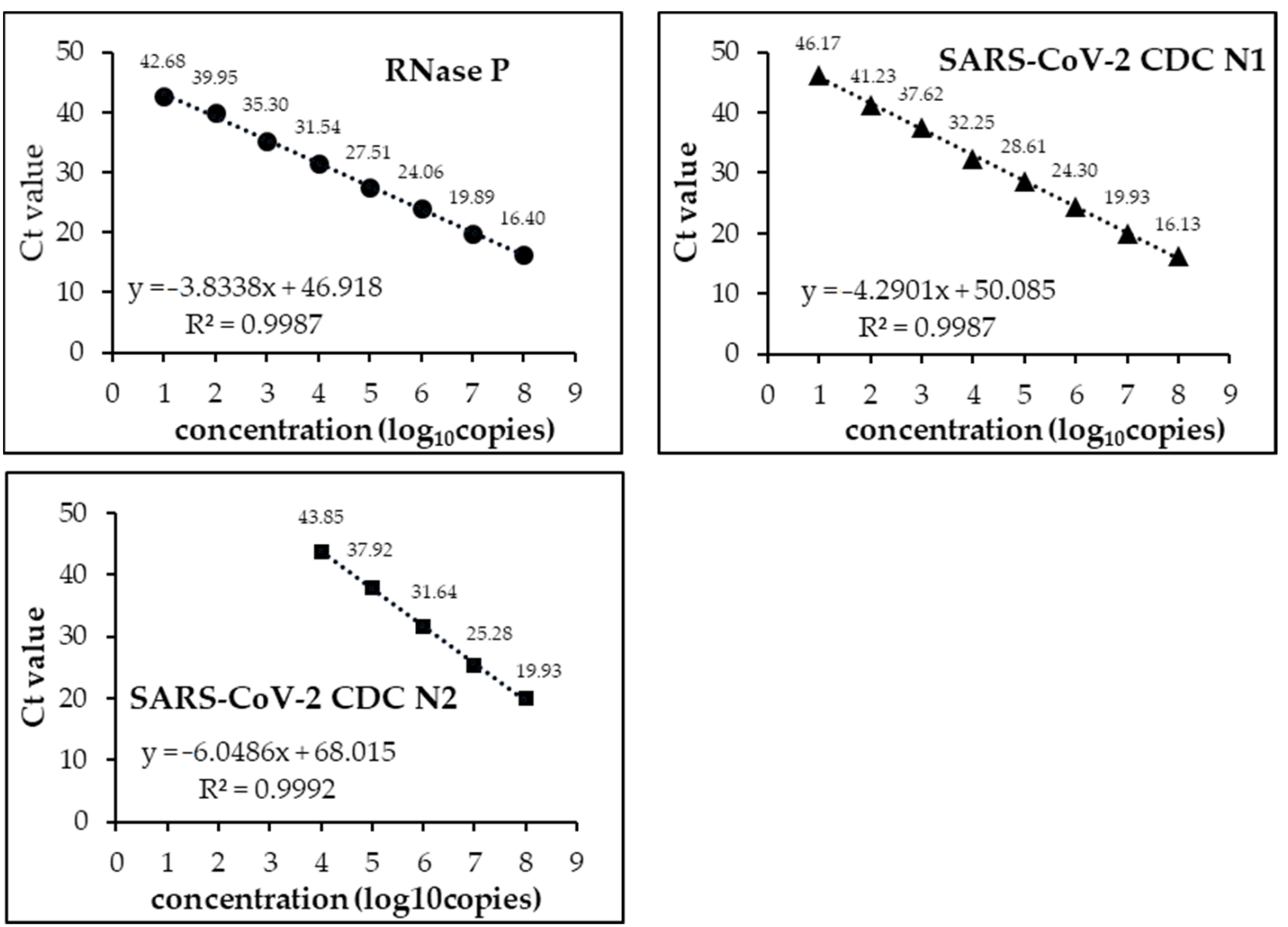

Figure 2. The correlation of each concentration of synthetic RNA and Ct value when the PCR1100 device was utilized to detect with multichannel. The $\mathrm{Ct}$ value against each concentration is demonstrated by the number above each symbol. $\mathrm{x}$ : $\log _{10}$ copies; y: Ct value.

\subsection{PCR1100 User-Friendliness}

Eight of the 10 participants were able to perform qPCR using the PCR1100 upon the first attempt without any problems. Although two of the participants produced an error upon their first attempt, they were able to carry out the steps error-free after receiving a brief re-explanation and additional pipette operation explanation (Figure 3). The screen display of the actual machine at that time is shown in Figure 4. The average $\mathrm{Ct}$ value of the 10 participants was 27.56 , and stable results were obtained. Therefore, it was confirmed that with simple explanation and training, people who do not have knowledge or experience in molecular biology can use this device correctly. 


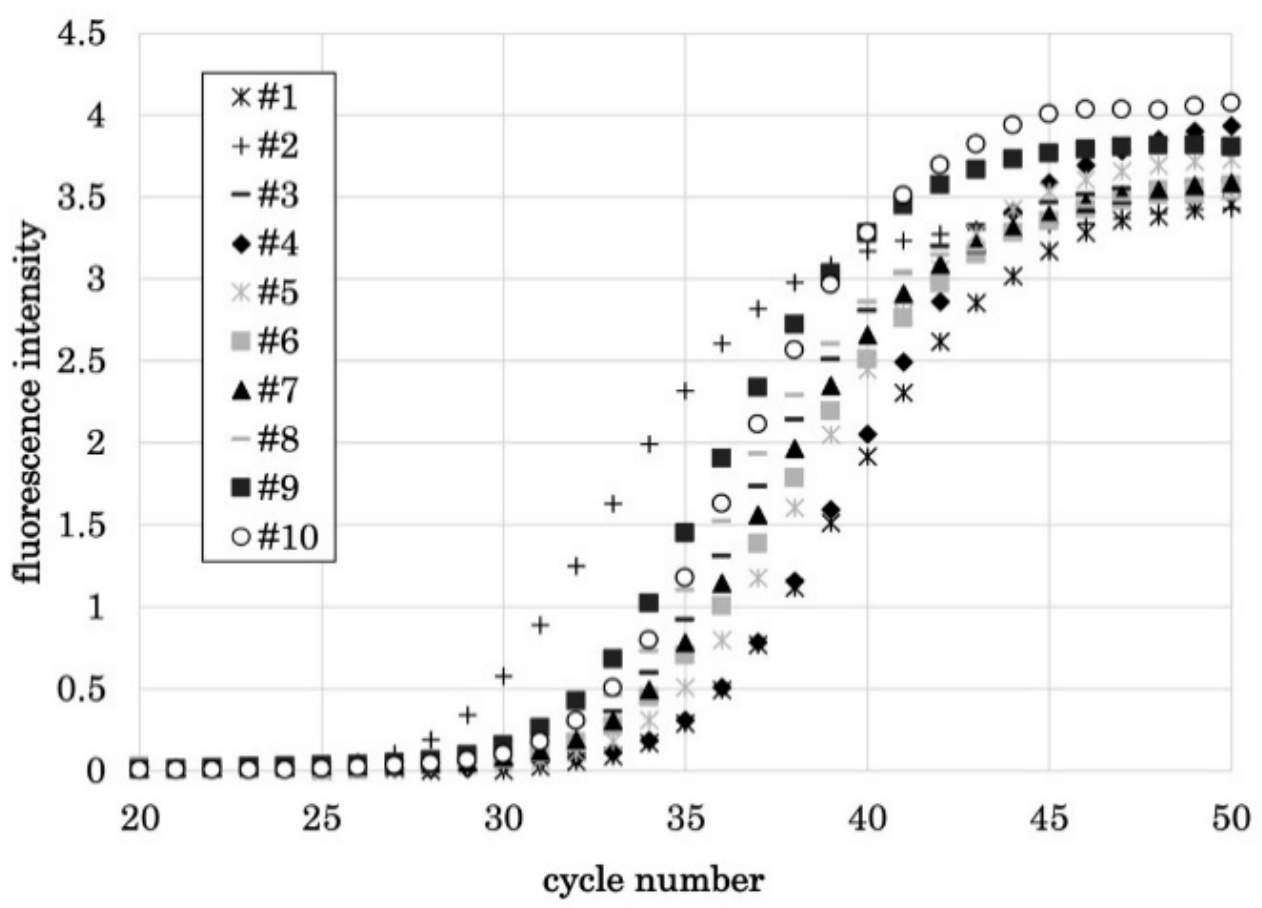

Figure 3. qPCR results of 10 subjects. Eight of the 10 subjects were able to perform qPCR for the first time without any problems. Two people were able to perform qPCR without any problem after a simple training. A stable result was obtained with an average $\mathrm{Ct}$ value of 27.56 .
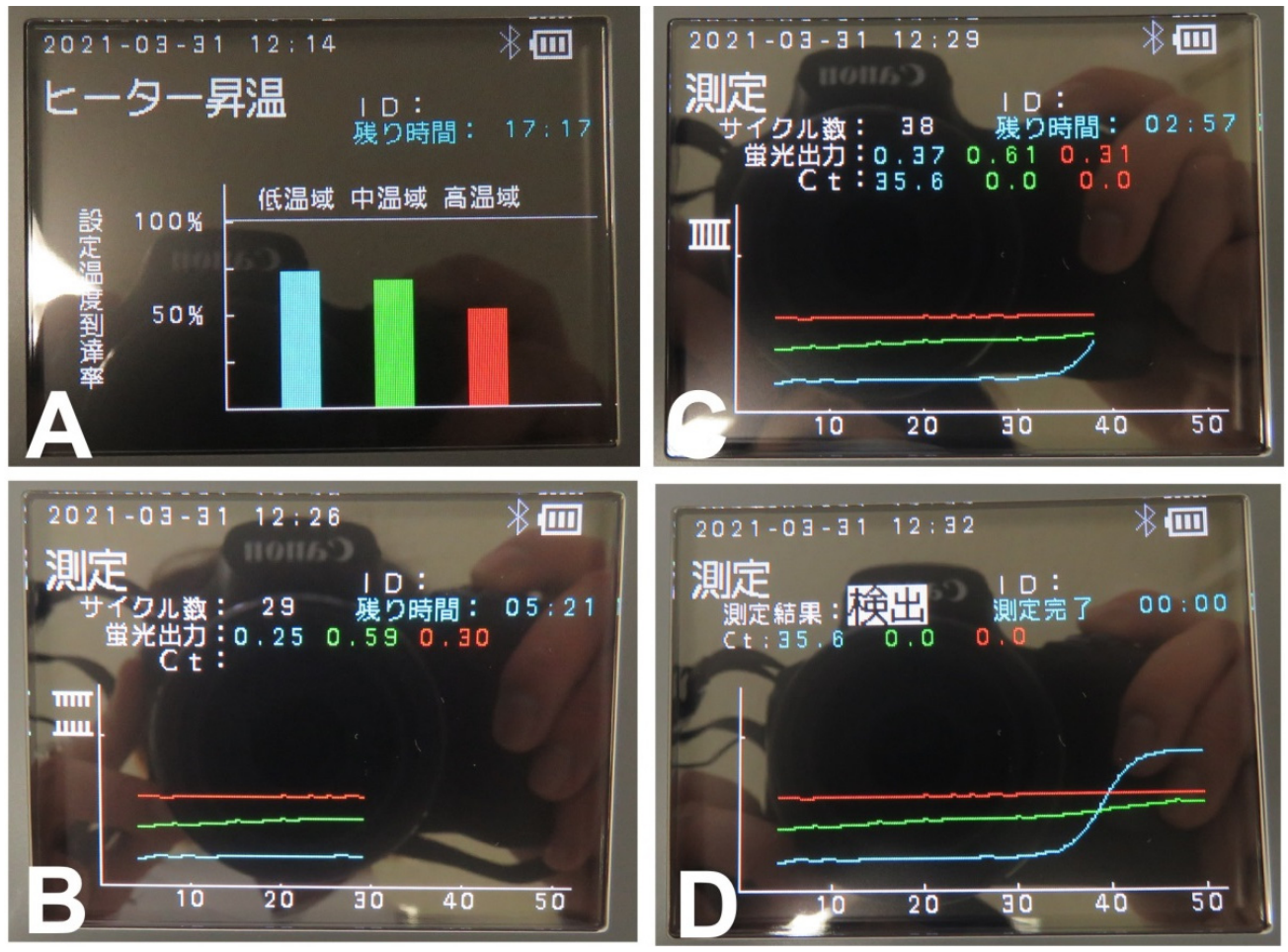

Figure 4. Screen display during qPCR with PCR1100: (A) The heat block heating up. (B) Amplification reaction. Three graphs are displayed as it progresses. Blue, RNase P; Green, CDC N1; Red, CDC N2. (C) The blue graph shows an increase (i.e., presence of RNA). The Ct value when the graph rises is displayed (here, it is 35.6). (D) The reaction continues up to 50 cycles. At the end of 50 cycles, the final measurement result and each $\mathrm{Ct}$ value are displayed. 


\section{3. qPCR Using a Trace Amount of Saliva as a Sample}

RNase P synthetic RNA was mixed into saliva without any pretreatment, and PCR1100 performed qPCR using this mixture as a sample. At first, when saliva was used as a stock solution sample, the high viscosity hindered the movement of the sample in the flow path chip, and qPCR did not operate normally. However, when saliva was diluted two-fold, qPCR operated normally, and contaminated RNase P synthetic RNA was detected. In addition, to prove that this result was not caused by the saliva of a specific subject, the same procedure was performed using representative saliva mixed with the saliva of five subjects, and qPCR performed normally. As a result, it was confirmed that this device can perform qPCR using saliva without any pretreatment as a sample (Table 3).

Table 3. qPCR results when using saliva mixed with RNase P synthetic RNA as a sample.

\begin{tabular}{ccc}
\hline Sample & Detection Status & Ct Value \\
\hline Saliva (undiluted solution) & Not detected & - \\
Saliva (diluted 2-fold with pure water) & Detected & 23.34 \\
Representative saliva (for 5 people) (diluted 2-fold & Detected & 28.50 \\
with pure water) & & \\
\hline
\end{tabular}

Next, since saliva originally contains RNase $\mathrm{P}$, it was examined whether it could be detected without adding RNase P synthetic RNA to the saliva sample in advance. As a result, it was possible to detect endogenous RNase P in saliva using two- or fourfold diluted saliva as a sample. Thus, it was confirmed that this device can detect RNA contained in saliva without pretreatment. However, since the $\mathrm{Ct}$ value exceeded 40 in the four-fold dilution, it was considered appropriate to dilute the saliva approximately two-fold (Table 4).

Table 4. qPCR results using saliva (without RNase P synthetic RNA contamination).

\begin{tabular}{ccc}
\hline Sample & Detection Status & Ct Value \\
\hline Saliva (diluted 2-fold with PBS) & Detected & 36.08 \\
Saliva (diluted 4-fold with PBS) & Detected & 42.34 \\
\hline
\end{tabular}

From the viewpoint of being simpler and reducing the risk of infection, it was examined whether a sample collected by the mouthwash method instead of the saliva spitting method could be used for the purpose of omitting the step of diluting saliva. As a result, it was confirmed that when a mouthwash with 1 or $2 \mathrm{~mL}$ of 10 -fold diluted PBS was used as a sample for 10 or $15 \mathrm{~s}$, endogenous RNase P in saliva could be detected using the mouthwash as a sample under any condition (Table 5). Furthermore, a mouthwash with physiological saline, which is easier to apply clinically, was used as a sample. As a result, it was confirmed that endogenous RNase P in saliva could be detected in mouthwash for $15 \mathrm{~s}$ with $2 \mathrm{~mL}$ of physiological saline (Table 5). From this, it was found that when clinically applying this device as a POCT, $2 \mathrm{~mL}$ of physiological saline for $15 \mathrm{~s}$ of mouthwash was an easy and stable method to use for sample collection. In addition, it was possible to detect endogenous RNase P in the frozen samples without any problems (Table 5).

Furthermore, to clarify factors that affect sample collection, we examined the samples at normal times, after meals, and after brushing. As a result, compared to normal times, diet was not affected and endogenous RNase P originally contained in saliva could be detected. As was detected after brushing, the $\mathrm{Ct}$ value tended to increase. It was confirmed that collecting a sample using this device should be avoided immediately after brushing. This result was the same for both diluted saliva and mouthwash (Table 6). 
Table 5. qPCR results when mouthwash is used as a sample.

\begin{tabular}{|c|c|c|c|c|c|c|}
\hline \multicolumn{5}{|c|}{ Sample (Collect $3 \mu \mathrm{L}$ from Mouthwash and Perform qPCR) } & \multirow{2}{*}{$\frac{\text { Detection Status }}{\text { Detected }}$} & \multirow{2}{*}{$\frac{\text { Ct Value }}{37.30}$} \\
\hline Wash & mouth & with & $1 \mathrm{~mL}$ & of 10 -fold diluted PBS for $10 \mathrm{~s}$ & & \\
\hline Wash & mouth & with & $2 \mathrm{~mL}$ & of 10 -fold diluted PBS for $10 \mathrm{~s}$ & Detected & 38.30 \\
\hline Wash & mouth & with & $1 \mathrm{~mL}$ & of 10 -fold diluted PBS for $15 \mathrm{~s}$ & Detected & 34.43 \\
\hline Wash & mouth & with & $2 \mathrm{~mL}$ & of 10 -fold diluted PBS for $15 \mathrm{~s}$ & Detected & 33.63 \\
\hline Wash & mouth & with & $2 \mathrm{~mL}$ & of saline for $15 \mathrm{~s}$ (subject 1 ) & Detected & 37.74 \\
\hline Wash & mouth & with & $2 \mathrm{~mL}$ & of saline for $15 \mathrm{~s}$ (subject 2) & Detected & 39.03 \\
\hline Wash & mouth & with & $2 \mathrm{~mL}$ & of saline for $15 \mathrm{~s}$ (subject 3 ) & Detected & 35.76 \\
\hline Wash & mouth & with & $2 \mathrm{~mL}$ & $\begin{array}{l}\text { of saline for } 15 \mathrm{~s} \text { (subject } 1 \text { ) } \\
\text { (After freezing for } 2 \text { weeks) }\end{array}$ & Detected & 35.45 \\
\hline Wash & mouth & with & $2 \mathrm{~mL}$ & $\begin{array}{l}\text { of saline for } 15 \text { s (subject } 2 \text { ) } \\
\text { (After freezing for } 2 \text { weeks) }\end{array}$ & Detected & 37.98 \\
\hline Wash & mouth & with & $2 \mathrm{~mL}$ & $\begin{array}{l}\text { of saline for } 15 \text { s (subject } 3 \text { ) } \\
\text { (After freezing for } 2 \text { weeks) }\end{array}$ & Detected & 35.14 \\
\hline
\end{tabular}

Table 6. Effect of diet and brushing (Ct value).

\begin{tabular}{lccc}
\hline \multirow{2}{*}{ Conditions for Sample Collection } & \multicolumn{2}{c}{ Diluted Saliva } \\
\cline { 2 - 3 } & 2-Fold with PBS & 4-Fold with PBS & Mouthwash \\
\hline Normal time (3 h after eating and & 36.08 & 42.34 & 37.12 \\
brushing) & 39.44 & 38.63 & 37.54 \\
After meals (30 min) & 42.15 & 40.60 & 41.15 \\
\hline After brushing (15 min) &
\end{tabular}

\subsection{Detection of SARS-CoV-2 Synthetic RNA}

We investigated whether this device could detect SARS-CoV-2 N1 and N2 synthetic RNA in saliva. As a control, when synthetic RNAs of RNase P, CDC N1, and CDC N2 were mixed with pure water and qPCR performed with the PCR1100, detection was successful. Thus, it was confirmed that there was no problem using the SARS-CoV-2 detection protocol set with this device. Therefore, SARS-CoV-2 N1 and N2 synthetic RNA were mixed with the mouthwash of four subjects, and qPCR was performed with the PCR1100 using this as a sample. As a result, it was confirmed that SARS-CoV-2 synthetic RNA can be detected using the mouthwash of any subject. From this, it was determined that mouthwash can be used as a sample for detecting SARS-CoV-2 with this device (Table 7). However, in the sample in which synthetic RNA was directly mixed with mouthwash, the Ct value at the time of detection tended to increase with the passage of time compared with the sample in which synthetic RNA was added to the premix in advance. This was attributed to the progress of RNA degradation by the saliva component, although detection was achieved with each of them (Table 7).

\subsection{Detection of SARS-CoV-2 Viral RNA from COVID-19 Patients}

We investigated whether SARS-CoV-2 viral RNA could be detected by this device using the mouthwash of COVID-19 patients who had been diagnosed as SARS-CoV-2 positive by the conventional qPCR test. Of the 20 participants who gave their consent, sampling was performed in 17 people and three were excluded due to the ambiguous date of the onset of symptoms. Initially, CDC N2 was not detected in all cases. This was considered to be a problem of sensitivity, which made it necessary to improve the concentration of primer and annealing temperature. In the future, adjustments should be made to improve the sensitivity of the test so that $\mathrm{N} 1$ and $\mathrm{N} 2$ can be detected to the same extent. As a result, CDC N1 could be detected without any problem in the subjects who had a short period from the onset of symptoms. This period was approximately 10 days (Table 8). As a typical case, in subject 12, SARS-CoV-2 virus RNA was detected with a $\mathrm{Ct}$ value of 35.7 on the 8 th day but was not detected on the 15th day (Figure 5). In subject 8 , the Ct value was detected at 38.4 on the 3rd day but was not detected on the 10th day 
(Figure 6). However, looking at the graph on the 10th day, an upward trend was observed in the graph near 50 cycles. It was presumed that a small amount of virus was present in the mouthwash around 10 days, which was considered to be proof that the detection limit was around 10 days. For all subjects, there was a tendency that the virus could not be detected in the mouthwash samples after $\sim 10$ days. However, there were cases, such as subject 2 , in which detection was possible after 10 days even if the period from onset of symptoms was long (Table 8).

Table 7. Detection of SARS-CoV-2 synthetic RNA (CDC IM1, CDC IM2) mixed in saliva samples.

\begin{tabular}{|c|c|c|c|c|}
\hline \multirow{2}{*}{ Sample } & \multirow{2}{*}{ Conditions } & \multicolumn{3}{|c|}{ Ct Value } \\
\hline & & RNase $\mathbf{P}$ & CDC N1 & CDC N2 \\
\hline Positive control & Synthetic RNA of $10^{7}$ copies each in pure water & 21.09 & 18.95 & 24.74 \\
\hline Subject 1 & Premix containing synthetic RNA+ Mouthwash $3 \mu \mathrm{L}$ & 38.40 & 18.96 & 37.54 \\
\hline Subject 1 & Premix + Mouthwash $3 \mu \mathrm{L}$ containing synthetic RNA & 33.97 & 31.44 & $>50$ \\
\hline Subject 2 & Premix containing synthetic RNA+ Mouthwash $3 \mu \mathrm{L}$ & 36.99 & 19.61 & 26.37 \\
\hline Subject 2 & Premix + Mouthwash $3 \mu \mathrm{L}$ containing synthetic RNA & 33.19 & 26.27 & 43.83 \\
\hline Subject 3 & Premix containing synthetic RNA+ Mouthwash $3 \mu \mathrm{L}$ & 35.62 & 19.92 & 26.87 \\
\hline Subject 3 & Premix + Mouthwash $3 \mu \mathrm{L}$ containing synthetic RNA & 32.39 & 27.50 & 43.59 \\
\hline Subject 4 & Premix containing synthetic RNA+ Mouthwash $3 \mu \mathrm{L}$ & 39.84 & 18.68 & 25.92 \\
\hline Subject 4 & Premix + Mouthwash $3 \mu \mathrm{L}$ containing synthetic RNA & 36.36 & 26.60 & 42.41 \\
\hline
\end{tabular}

Table 8. Detection of SARS-CoV-2 viral RNA (CDC Nl) in COVID-19 patients by PCR1100.

\begin{tabular}{|c|c|c|c|c|c|}
\hline \multirow{2}{*}{$\begin{array}{l}\text { Subjects } \\
\text { Age Sex }\end{array}$} & \multicolumn{3}{|c|}{$\begin{array}{l}\text { Period from Onset of Symptom } \\
\text { (Days)/Detect (Ct Value) or Not (-) }\end{array}$} & \multirow[t]{2}{*}{ Symptom (Period, Days) } & \multirow[t]{2}{*}{ Past History } \\
\hline & 1st & 2nd & $3 r d$ & & \\
\hline 1. $38 \mathrm{M}$ & $13 / 44.6$ & $20 /(-)$ & & Fever (6), malaise, dysgeusia & HT, DM, HL, CCF \\
\hline 2. $90 \mathrm{M}$ & $7 / 29.3$ & $14 / 34.5$ & $21 / 38.8$ & Fever (8), breathing difficulty & HT, DM, CKD \\
\hline 3. $56 \mathrm{~F}$ & $18 /(-)$ & $25 /(-)$ & & Fever, respiratory management (7) & n.p. \\
\hline 4. $34 \mathrm{M}$ & $11 /(-)$ & & & Fever (10), dysgeusia & n.p. \\
\hline $5.34 \mathrm{~F}$ & $7 / 38.1$ & $14 /(-)$ & & Fever (5), breathing difficulty & DM, HT, obesity \\
\hline 6. $47 \mathrm{~F}$ & $11 /(-)$ & $18 /(-)$ & & Fever (11), dysgeusia & $\begin{array}{l}\text { CKD, thyroid and } \\
\text { parathyroid cancer }\end{array}$ \\
\hline 7. $67 \mathrm{M}$ & Exclusion & & & & \\
\hline 8. $47 \mathrm{M}$ & $3 / 38.4$ & $10 /(-)$ & & Fever (5), cough & $\mathrm{CKD}, \mathrm{HD}, \mathrm{DM}$ \\
\hline $9.76 \mathrm{M}$ & $9 / 45.2$ & & & Fever (7), breathing difficulty & n.p. \\
\hline 10. $44 \mathrm{M}$ & $7 / 36.9$ & $14 /(-)$ & & Fever (10), breathing difficulty & DM, HT, HL \\
\hline 11. $30 \mathrm{M}$ & $10 /(-)$ & & & Fever (10), breathing difficulty & n.p. \\
\hline 12. $22 \mathrm{M}$ & $8 / 35.7$ & $15 /(-)$ & & Fever (10), diarrhea & n.p. \\
\hline 13. $57 \mathrm{M}$ & $10 /(-)$ & & & cough, breathing difficulty & $\mathrm{DM}$ \\
\hline 14. $61 \mathrm{M}$ & $8 / 34.2$ & & & Fever (13), dysgeusia & $\begin{array}{c}\text { integration } \\
\text { disorder syndrome }\end{array}$ \\
\hline 15. $61 \mathrm{M}$ & $25 /(-)$ & & & Fever (15), breathing difficulty & DM, HT \\
\hline 16. $34 \mathrm{M}$ & $11 / 34.1$ & & & Fever (11), breathing difficulty & DM \\
\hline 17. $61 \mathrm{M}$ & Exclusion & & & & \\
\hline 18. $54 \mathrm{M}$ & Exclusion & & & & \\
\hline 19. $81 \mathrm{M}$ & $1 / 40.2$ & $8 / 37.7$ & & Fever (1), pneumonia & $\mathrm{HT}^{* 1}$ \\
\hline $20.60 \mathrm{~F}$ & $5 / 40.9$ & $12 /(-)$ & & Fever (4), breathing difficulty & CKD, HD \\
\hline
\end{tabular}

HT: hypertension, DM: diabetes mellitus, HL: hyperlipemia, CCF: chronic cardiac failure, CKD: chronic kidney disease, and HD: hemodialysis. ${ }^{*}$ : first vaccination 5 days before onset of symptoms. 

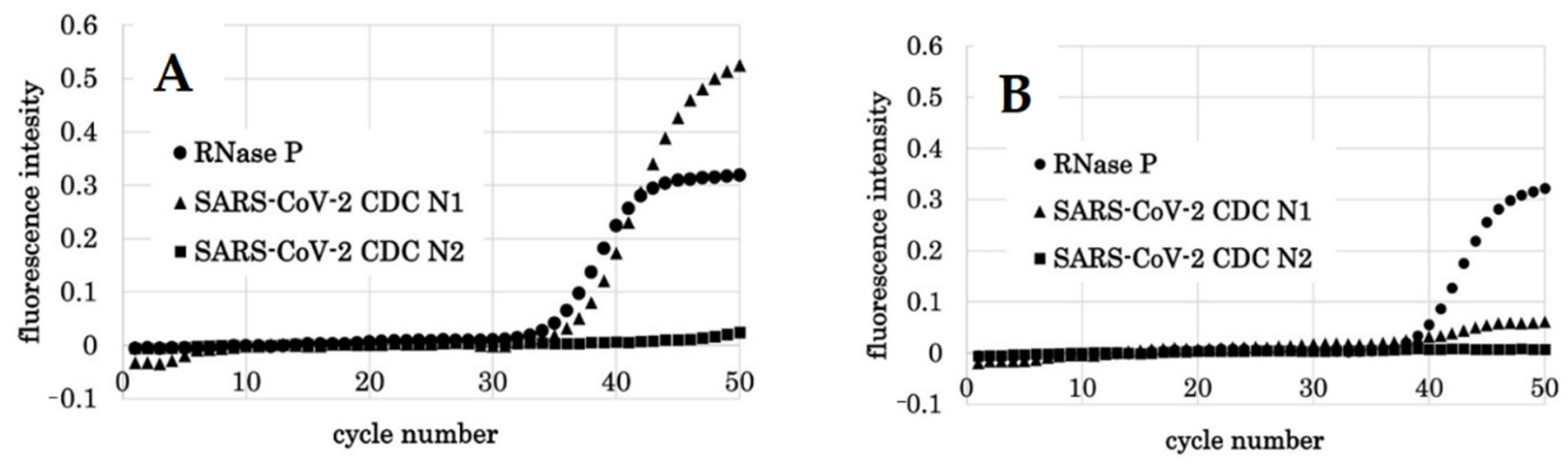

Figure 5. qPCR results by PCR1100 of subject 12. (A) Results of the first qPCR (8th day after the onset of symptoms). RNase $\mathrm{P}$ was detected with a $\mathrm{Ct}$ value of 34.4, indicating that there was no problem with the PCR reaction. CDC N1 increased at a Ct value of 35.7, and SARS-CoV-2 viral RNA was detected. At this time, CDC N2 was not detected. (B) Results of the second qPCR (15 days after the onset of symptoms). RNase P was detected with a Ct value of 38.4, indicating that there was no problem with the PCR reaction. CDC N1 was not detected.
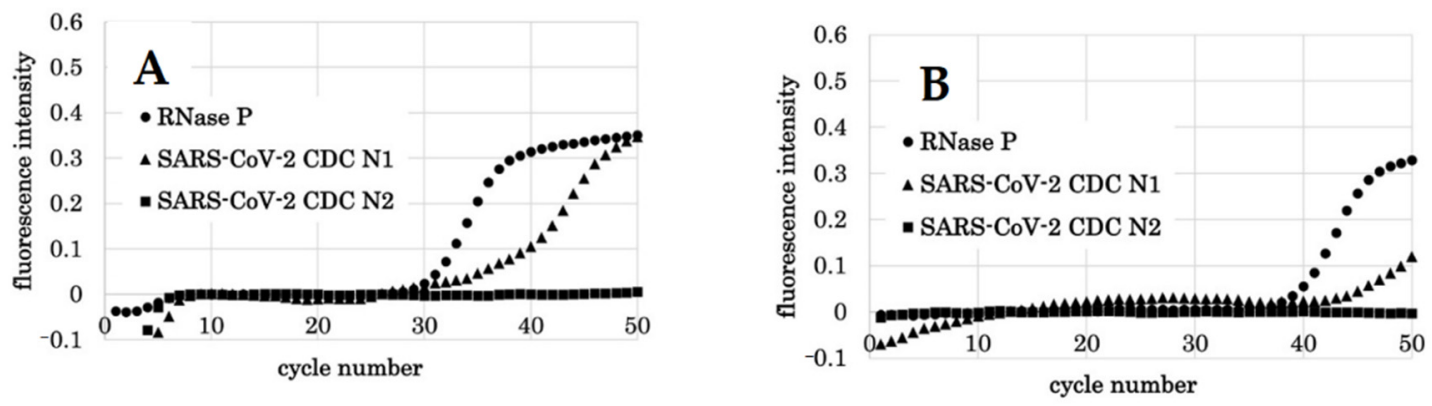

Figure 6. qPCR results by PCR1100 of subject 8. (A) Results of the first qPCR (3rd day after the onset of symptoms). RNase $\mathrm{P}$ was detected with a Ct value of 29.8, indicating that there was no problem with the PCR reaction. CDC N1 increased at a Ct value of 38.4, and SARS-CoV-2 viral RNA was detected. At this time, CDC N2 was not detected. (B) Results of the second qPCR (10 days after the onset of symptoms). RNase P was detected with a Ct value of 38.4, which indicated that there was no problem with the PCR reaction. CDC N1 was not detected. However, the graph showed an upward trend near 50 cycles.

\section{Discussion}

Pandemic control of COVID-19 includes preventative measures, such as social distancing, wearing masks, and maintaining good hand hygiene, but as a complement, isolation of positive cases and extensive population screening are important preventative measures [1] However, SARS-CoV-2 virus RNA detection by conventional RT-qPCR techniques, such as using nasopharyngeal swab samples, are costly, have a long turnaround time, require specialized personnel, and might require a device that is unavailable. Therefore, extensive screening tests have not been conducted [4]. However, in some countries, such as China, the qPCR test is being used for screening. However, it should be taken into consideration that the actual conditions of testing differ greatly between countries, and the infection status and the degree of containment aimed at are also different. Since there is no debate about the superiority of the qPCR test itself, it is significant that various qPCR devices and sample collection methods exist as options. If it can be selected according to the situation of each country, it is considered that more effective infection control measures against the SARS-CoV-2 pandemic can be achieved. An antigen test is an alternative test method to the current qPCR test. This test is user-friendly, low-cost, quick, and utilizes a small test device, so it can be widely available [7]. However, the main disadvantage is that the sensitivity is lower than that of the qPCR test, which makes it less suitable as a screening test $[8,9]$. In the future, it is expected that mutations in the virus will occur. At this time, there is a possibility that the mutant strain cannot be dealt with by the antigen test applying the antigen-antibody reaction. However, if it is qPCR, it can be applied 
immediately by setting a new primer in the mutant part. From this, it is considered that the qPCR method is highly useful in the future. Recently, the development of a LAMP test using saliva as a sample [10] and an attempt to place a satellite laboratory in the inpatient ward of a COVID-19 patient to perform a rapid test [11] have been reported. Various other test methods have been developed and studied [12-16], but none have achieved the same sensitivity and specificity as the conventional qPCR test. Recently, POCT is a test concept that has been attracting attention, as several small devices that can perform qPCR in a short time have been developed, which can overcome many of the aforementioned problems. Attempts to apply these as SARS-CoV-2 detection devices are being reported [17]. The introduction of POCT equipment is cost-effective, provides detection capabilities that are comparable to conventional qPCR equipment, and eliminates the need for large laboratories and equipment. It is very useful and suitable as a screening test at the time of a pandemic such as COVID-19. Therefore, since January 2020, various researchers and companies have focused on the development of POCT testing devices for rapid diagnosis of SARS-CoV-2. As mentioned earlier, several types of POCT devices have been developed; they have achieved antibody detection [18-23], antigen detection [24-26], and nucleic acid detection [27-29]. The PCR1100 used in this study is a POCT device that focuses on nucleic acid detection, and as revealed in this study, it is user-friendly and can be performed easily, even by medical staff who have no knowledge or experience in molecular cell biology. Thus, it was proven that qPCR testing can be performed in a short time by using this device, even in hospitals and small clinics regardless of the practice (i.e., dentistry, medicine), without skilled clinical laboratory technicians and specialized staff.

On the other hand, the currently used sample collection method, a nasopharyngeal swab, poses the risk of infection due to the droplets at the time of collection, and the quality of the sample varies depending on the collection technique [2,3,30-33]. In order to overcome these problems, various body fluids, such as saliva, tears, and so on, have been verified to be effective samples for the purpose of facilitating safer sampling protocol [34-41]. Among these alternative sample types, saliva has been reported to be as sensitive and specific as nasopharyngeal swabs compared to other body fluids [42,43]. In this study, with the aim to develop a safer yet simpler, easy-to-use diagnostic method using the PCR1100 as a POCT device, saliva was used as a sample. As a result, when the undiluted saliva was used as a sample, its viscosity became a problem, and its movement in the flow path chip was hindered; therefore, the device did not operate normally. However, by diluting the saliva more than two-fold, the device operated normally, and RNase P synthetic RNA mixed in saliva could be detected. However, when the saliva was diluted four-fold or more, the $\mathrm{Ct}$ value at the time of detection tended to increase, so it was confirmed that dilution of approximately two-fold is appropriate. We also examined whether RNA of RNase P originally contained in saliva could be detected and found that endogenous RNase P could be detected without any pretreatment. Furthermore, to eliminate the step of diluting saliva and thus enable a simpler and safer sample collection, a 15-s mouthwash with $2 \mathrm{~mL}$ of physiological saline was tried as a sample. As a result, it was confirmed that endogenous RNase P could be detected. Moreover, this mouthwash could be used directly as a sample without any pretreatment. However, it was also confirmed that the timing of mouthwash collection impacted the sensitivity of detection; testing should be avoided immediately after brushing, although the influence of eating food is small.

Finally, we examined whether SARS-CoV-2 viral RNA could be detected using the mouthwash of a COVID-19 patient as a sample. SARS-CoV-2 synthetic RNA mixed into the mouthwash could be detected under the conditions established so far without any problem. Therefore, when this diagnostic method was performed on patients undergoing hospitalization under the diagnosis of COVID-19 using mouthwash as a sample, SARSCoV-2 virus RNA could be detected without any problem. In addition, the detection of SARS-CoV-2 viral RNA depends on the period from onset of symptoms. It was confirmed that SARS-CoV-2 viral RNA can be detected using this device. As was reported in previous reports [42-44], the detection results when using mouthwash suggested that there is a 
detection limit depending on the period from the onset of symptoms, which is around 10 days. It is necessary to keep this in mind when using PCR1100 as a POCT device and in future screenings, but it was found that the device's performance was sufficient for achieving the intended purpose. Table 9 summarizes the advantages of PCR 1100 over current qPCR devices. In this study, results from PCR 1100 could not be compared with those from conventional qPCR devices under current Japanese infection control regulations. However, it was found that the method using PCR 1100 could detect SARS-CoV-2 in a mouthwash sample containing a small amount of saliva. In order to verify the detection accuracy of PCR 1100, the number of samples will be increased and compared with the results obtained using conventional qPCR, which will be reported in the near future. In addition, although we did not limit the $\mathrm{Ct}$ value at the time of N1 detection this time, in the future, it will be necessary to adjust the $\mathrm{Ct}$ value for diagnosing SARS-CoV-2 positivity. In addition, N2 could not be detected at all in this study. This was considered to be a problem of sensitivity, which can likely be resolved by as adjustments to certain settings such as the primer concentration and annealing temperature. In the future, we think it will be necessary to find a setting that can detect N1 and N2 to the same extent. Improvement of $\mathrm{N} 2$ detection conditions is now nearly complete and is in the process of final confirmation for actual COVID-19 patients. We plan to release the data in the near future. Moreover, by performing this test frequently in the future, it may be possible to utilize it not only for the detection of SARS-CoV-2 virus, but also for the determining the course of treatment and discharge time. Either way, as a screening tests, this method, which can quickly and easily diagnose the presence or absence of SARS-CoV-2 viral RNA contained in saliva, can promote more extensive testing in small clinics and contribute to infection control [44-46]. This diagnostic method is an effective screening test that supports the early diagnosis and management of COVID-19 infection.

Table 9. Advantages of the PCR1100 device compared with conventional qPCR devices.

\begin{tabular}{lll}
\hline & \multicolumn{1}{c}{ PCR1100 } & \multicolumn{1}{c}{ Conventional qPCR Device } \\
\hline $\begin{array}{l}\text { Turnaround time } \\
\text { Sample }\end{array}$ & $\begin{array}{l}\text { approximately 18 min } \\
\text { mouthwash } \\
\text { skilled specialist, } \\
\text { clinical laboratory technician } \\
\text { mobile (POCT) }\end{array}$ & $\begin{array}{l}\text { a few hours } \\
\text { nasopharyngeal swab, saliva, etc. }\end{array}$ \\
Ease of handling & anyone \\
\hline
\end{tabular}

The possibility of spreading COVID-19 infection via saliva aerosol has been pointed out, and medical practice where saliva aerosol is generated, especially in dentistry, has severely restricted the medical care provided, thus causing serious public health problems [47,48]. If this diagnostic method can be applied, performing a screening test before providing outpatient treatment will become easier in small clinics and dental clinics. This result makes it possible to implement an infection control measure that enables health care professionals to perform treatments that generate aerosols with less risk of spreading COVID-19. Successful infection control in the future depends on effective measures such easy-to-use screening methods with a rapid turnaround time that can be operated in small clinics without specialized laboratory equipment and technicians. We are confident that this diagnostic method will greatly contribute to the establishment of new trends in screening for better infection control in the future.

\section{Conclusions}

This diagnostic method is a simple and rapid qPCR test that produces accurate results from the mouthwash of COVID-19 patients. In addition to its efficacy and rapid results, this diagnostic method is easy to use and cost effective, which makes it practical for small clinics without specialized technicians to implement this screening test to minimize the risk of the virus' spread. In future studies, we plan to increase the number of cases tested at multiple centers to confirm the accuracy of this diagnostic method. 
Supplementary Materials: The following are available online at https:/ / www.mdpi.com/article/ 10.3390/diagnostics11112024/s1.

Author Contributions: R.T.-T. conceived, designed, and performed the experiments, analyzed the data, and wrote the manuscript. M.M. designed and performed the experiments and analyzed the data. C.T.-I. performed the experiments. S.I. performed the experiments. T.H. performed the experiments. T.A. performed the experiments. A.F. performed the experiments. Y.H. performed the experiments. S.S. conceived the experiments and provided the specimens. K.S. conceived and designed the experiment and provided the specimens. All authors have read and agreed to the published version of the manuscript.

Funding: This research was funded by JSPS KAKENHI (grant numbers 20K10150 and 20K10104).

Institutional Review Board Statement: The study was conducted according to the guidelines of the Declaration of Helsinki and approved by the Ethics Committee of the Faculty of Dentistry, Tsurumi University, Japan (No. 1834, approval date is 12 November 2021, 1841, approval date is 13 January 2021, 121002, approval date is 10 May 2021), and the Saiseikai Yokohamashi Tobu Hospital Ethics Review Committee (No. 20210012, approval date is 4 June 2021).

Informed Consent Statement: Written informed consent were obtained from the patients and subjects for publication of this article and accompanying images.

Data Availability Statement: The data that support the findings of this study are available from the corresponding author upon reasonable request.

Conflicts of Interest: The authors declare no conflict of interest.

\section{References}

1. Udugama, B.; Kadhiresan, P.; Kozlowski, H.N.; Malekjahani, A.; Osborne, M.; Li, V.Y.C.; Chen, H.; Mubareka, S.; Gubbay, J.B.; Chan, W.C.W. Diagnosing COVID-19: The Disease and Tools for Detection. ACS Nano 2020, 14, 3822-3835. Available online: https:/ / www.ncbi.nlm.nih.gov/pmc/articles/PMC7144809/ (accessed on 10 December 2020). [CrossRef]

2. Evans, R.W. Diagnostic Testing for SARS-CoV-2; WHO: Geneva, Switzerland, 2020.

3. Ravi, N.; Cortade, D.L.; Ng, E.; Wang, S.X. Diagnostics for SARS-CoV-2 Detection: A Comprehensive Review of the FDA-EUA COVID-19 Testing Landscape. Biosens. Bioelectron. 2020, 165, 112454. [CrossRef] [PubMed]

4. Dinnes, J.; Deeks, J.J.; Adriano, A.; Berhane, S.; Davenport, C.; Dittrich, S.; Emperador, D.; Takwoingi, Y.; Cunningham, J.; Beese, S.; et al. Rapid, Point-of-Care Antigen and Molecular-Based Tests for Diagnosis of SARS-CoV-2 Infection. Cochrane Database Syst. Rev. 2020, 8, CD013705. Available online: https:/ /www.cochranelibrary.com/cdsr/doi/10.1002/14651858.CD013705/full (accessed on 10 December 2020). [PubMed]

5. Jung, Y.J.; Park, G.S.; Moon, J.H.; Ku, K.; Beak, S.H.; Kim, S.; Park, E.C.; Park, D.; Lee, J.H.; Byeon, C.W.; et al. Comparative Analysis of Primer-Probe Sets for the Laboratory Confirmation of SARS-CoV-2. bioRxiv 2020, 11, 2513-2523. [CrossRef]

6. Shirato, K.; Nao, N.; Kawase, M.; Kageyama, T. An Ultra-Rapid Real-Time RT-PCR Method Using PCR1100 for Detecting Human Orthopneumovirus. Jpn. J. Infect. Dis. 2020, 73, 465-468. [CrossRef] [PubMed]

7. Porte, L.; Legarraga, P.; Vollrath, V.; Aguilera, X.; Munita, J.M.; Araos, R.; Pizarro, G.; Vial, P.; Iruretagoyena, M.; Dittrich, S.; et al. Evaluation of a novel antigen-based rapid detection test for the diagnosis of SARS-CoV-2 in respiratory samples. Int. J. Infect. Dis. 2020, 99, 328-333. [CrossRef]

8. Joung, C.J.; Ladha, A.; Saito, M.; Segel, M.; Bruneau, R.; Huang, M.W.; Kim, N.-G.; Yu, X.; Li, J.; Walker, B.D.; et al. Point-of-Care Testing for COVID-19 Using Sherlock Diagnostics. medRxiv 2020. Available online: https:/ / www.ncbi.nlm.nih.gov/pmc/articles / PMC7273289/ (accessed on 10 December 2020).

9. Gibani, M.M.; Toumazou, C.; Sohbati, M.; Sahoo, R.; Karvela, M.; Hon, T.K.; De Mateo, S.; Burdett, A.; Leung, K.Y.F.; Barnett, J.; et al. Assessing a Novel, Lab-Free, Point-of-Care Test for SARS-CoV-2 (CovidNudge): A Diagnostic Accuracy Study. Lancet Microbe 2020, 1, e300-e307. [CrossRef]

10. Davidson, J.L.; Wang, J.; Maruthamuthu, M.K.; Dextre, A.; Pascual-Garrigos, A.; Mohan, S.; Putikam, S.V.S.; Osman, F.O.I.; McChesney, D.; Seville, J.; et al. A paper-based colorimetric molecular test for SARS-CoV-2 in saliva. Biosens. Bioelectron. X 2021, 9, 100076. [CrossRef]

11. Yau, F.; Ferreira, R.; Kamali, R.; Bird, P.W.; Halliwell, R.; Patel, H.; Nicoara, D.C.; Woltmann, G.; Tang, J.W. Clinical utility of a rapid 'on-demand' laboratory-based SARS-CoV-2 diagnostic testing service in an acute hospital setting admitting COVID-19 patients. Clin. Infect. Pract. 2021, 12, 100086. [CrossRef]

12. Taki, K.; Yokota, I.; Fukumoto, T.; Iwasaki, S.; Fujisawa, S.; Takahashi, M.; Negishi, S.; Hayasaka, K.; Sato, K.; Oguri, S.; et al. SARS-CoV-2 Detection by Fluorescence Loop-Mediated Isothermal Amplification with and Without RNA Extraction. J. Infect. Chemother. 2021, 27, 410-412. Available online: http:/ / www.sciencedirect.com/science/article/pii/S1341321X20303998 (accessed on 10 December 2020). [CrossRef] 
13. Nawattanapaiboon, K.; Pasomsub, E.; Prombun, P.; Wongbunmak, A.; Jenjitwanich, A.; Mahasupachai, P.; Vetcho, P.; Chayrach, C.; Manatjaroenlap, N.; Samphaongern, C.; et al. Colorimetric Reverse Transcription Loop-Mediated Isothermal Amplification (RT-LAMP) as a Visual Diagnostic Platform for the Detection of the Emerging Coronavirus SARS-CoV-2. Analyst 2021, 146, 471-477. Available online: https://pubs.rsc.org/en/content/articlelanding/2021/an/d0an01775b (accessed on 10 December 2020). [CrossRef]

14. Xia, S.; Chen, X. Single-Copy Sensitive, Field-Deployable, and Simultaneous Dual-Gene Detection of SARS-CoV-2 RNA via Modified RT-RPA. Cell Discov. 2020, 6, 37. [CrossRef]

15. Behrmann, O.; Bachmann, I.; Spiegel, M.; Schramm, M.; Abd El Wahed, A.; Dobler, G.; Dame, G.; Hufert, F.T. Rapid Detection of SARS-CoV-2 by Low Volume Real-Time Single Tube Reverse Transcription Recombinase Polymerase Amplification Using an exo Probe with an Internally Linked Quencher (exo-IQ). Clin. Chem. 2020, 66, 1047-1054. Available online: https:/ /www.ncbi.nlm. nih.gov/pmc/articles/PMC7239256/ (accessed on 10 December 2020). [CrossRef]

16. Harrington, A.; Cox, B.; Snowdon, J.; Bakst, J.; Ley, E.; Grajales, P.; Maggiore, J.; Kahn, S. Comparison of Abbott ID Now and Abbott m2000 Methods for the Detection of SARS-CoV-2 from Nasopharyngeal and Nasal Swabs from Symptomatic Patients. J. Clin. Microbiol. 2020, 58, e00798-20. Available online: https:/ /www.ncbi.nlm.nih.gov/pmc/articles/PMC7383519/ (accessed on 10 December 2020). [CrossRef] [PubMed]

17. Renzoni, A.; Perez, F.; Ngo Nsoga, M.T.; Yerly, S.; Boehm, E.; Gayet-Ageron, A.; Kaiser, L.; Schibler, M. Analytical Evaluation of Visby Medical RT-PCR Portable Device for Rapid Detection of SARS-CoV-2. Diagnostics 2021, 11, 813. [CrossRef]

18. Hou, H.; Wang, T.; Zhang, B.; Luo, Y.; Mao, L.; Wang, F.; Wu, S.; Sun, Z. Detection of IgM and IgG Antibodies in Patients with Coronavirus disease 2019. Clin. Transl. Immunol. 2020, 9, e01136. [CrossRef] [PubMed]

19. Kontou, P.I.; Braliou, G.G.; Dimou, N.L.; Nikolopoulos, G.; Bagos, P.G. Antibody Tests in Detecting SARS-CoV-2 Infection: A Meta-Analysis. Diagnostics 2020, 10, 319. [CrossRef] [PubMed]

20. Infantino, M.; Grossi, V.; Lari, B.; Bambi, R.; Perri, A.; Manneschi, M.; Terenzi, G.; Liotti, I.; Ciotta, G.; Taddei, C.; et al. Diagnostic Accuracy of an Automated Chemiluminescent Immunoassay for Anti-SARS-CoV-2 IgM and IgG Antibodies: An Italian Experience. J. Med. Virol. 2020, 92, 1671-1675. [CrossRef]

21. Chuan, J.; Gong, B.; Shuai, P.; Zhou, Y.; Zhang, Y.; Jiang, Z.; Zhang, D.; Liu, X.; Ma, S. Detection of serum IgM and IgG for COVID-19 diagnosis. Sci. China 2020, 63, 777-780.

22. Wen, T.; Huang, C.; Shi, F.J.; Zeng, X.Y.; Lu, T.; Ding, S.N.; Jiao, Y.J. Development of a Lateral Flow Immunoassay Strip for Rapid Detection of IgG Antibody Against SARS-CoV-2 Virus. Analyst 2020, 145, 5345-5352. [CrossRef] [PubMed]

23. Li, Z.; Yi, Y.; Luo, X.; Xiong, N.; Liu, Y.; Li, S.; Sun, R.; Wang, Y.; Hu, B.; Chen, W.; et al. Development and Clinical Application of a Rapid IgM-IgG Combined Antibody Test for SARS-CoV-2 Infection Diagnosis. J. Med. Virol. 2020, 92, 1518-1524. [CrossRef]

24. Cheng, M.P.; Papenburg, J.; Desjardins, M.; Kanjilal, S.; Quach, C.; Libman, M.; Dittrich, S.; Yansouni, C.P. Diagnostic Testing for Severe Acute Respiratory Syndrome-Related Coronavirus 2: A Narrative Review. Ann. Intern. Med. 2020, 172, 726-734. [CrossRef]

25. Sheridan, C. Fast, Portable Tests Come Online to Curb Coronavirus Pandemic. Nat. Biotechnol. 2020, 38, 515-518. [CrossRef] [PubMed]

26. Ji, T.; Liu, Z.; Wang, G.; Guo, X.; Akbar Khan, S.; Lai, C.; Chen, H.; Huang, S.; Xia, S.; Chen, B.; et al. Detection of COVID-19: A Review of the Current Literature and Future Perspectives. Biosens. Bioelectron. 2020, 166, 112455. [CrossRef]

27. Tang, Y.W.; Schmitz, J.E.; Persing, D.H.; Stratton, C.W. Laboratory Diagnosis of COVID-19: Current Issues and Challenges. J. Clin. Microbiol. 2020, 58, e00512-20. [CrossRef] [PubMed]

28. Vashist, S.K. In Vitro Diagnostic Assays for COVID-19: Recent Advances and Emerging Trends. Diagnostics 2020, 10, 202. [CrossRef]

29. Adachi, D.; Johnson, G.; Draker, R.; Ayers, M.; Mazzulli, T.; Talbot, P.J.; Tellier, R. Comprehensive Detection and Identification of Human Coronaviruses, Including the SARS-Associated Coronavirus, with a Single RT-PCR Assay. J. Virol. Methods 2004, 122, 29-36. [CrossRef]

30. Czumbel, L.M.; Kiss, S.; Farkas, N.; Mandel, I.; Hegyi, A.; Nagy, Á.; Lohinai, Z.; Szakács, Z.; Hegyi, P.; Steward, M.C.; et al. Saliva as a Candidate for COVID-19 Diagnostic Testing: A Meta-Analysis. Front. Med. 2020, 7, 465. [CrossRef]

31. Sapkota, D.; Søland, T.M.; Galtung, H.K.; Sand, L.P.; Giannecchini, S.; To, K.K.W.; Mendes-Correa, M.C.; Giglio, D.; Hasséus, B.; Braz-Silva, P.H. COVID-19 Salivary Signature: Diagnostic and Research Opportunities. J. Clin. Pathol. 2020, 74, 344-349. [CrossRef]

32. Marty, F.M.; Chen, K.; Verrill, K.A. How to Obtain a Nasopharyngeal Swab Specimen. N. Engl. J. Med. 2020, 382, e76. [CrossRef]

33. Fernandes, L.L.; Pacheco, V.B.; Borges, L.; Athwal, H.K.; de Paula Eduardo, F.; Bezinelli, L.; Correa, L.; Jimenez, M.; Dame-Teixeira, N.; Lombaert, I.M.A.; et al. Saliva in the Diagnosis of COVID-19: A Review and New Research Directions. J. Dent. Res. 2020, 99, 1435-1443. [CrossRef]

34. Barat, B.; Das, S.; De Giorgi, V.; Henderson, D.K.; Kopka, S.; Lau, A.F.; Miller, T.; Moriarty, T.; Palmore, T.N.; Sawney, S.; et al. Pooled Saliva Specimens for SARS-CoV-2 Testing. J. Clin. Microbiol. 2021, 59, e02486-20. [CrossRef] [PubMed]

35. Braz-Silva, P.H.; Mamana, A.C.; Romano, C.M.; Felix, A.C.; de Paula, A.V.; Fereira, N.E.; Buss, L.F.; Tozetto-Mendoza, T.R.; Caixeta, R.A.V.; Leal, F.E.; et al. Performance of at-Home Self-Collected Saliva and Nasal-Oropharyngeal Swabs in the Surveillance of COVID-19. J. Oral Microbiol. 2020, 13, 1858002. [CrossRef] [PubMed]

36. Mesoraca, A.; Margiotti, K.; Viola, A.; Cima, A.; Sparacino, D.; Giorlandino, C. Evaluation of SARS-CoV-2 Viral RNA in Fecal Samples. Virol. J. 2020, 17, 86. [CrossRef] 
37. Pasomsub, E.; Watcharananan, S.P.; Boonyawat, K.; Janchompoo, P.; Wongtabtim, G.; Suksuwan, W.; Sungkanuparph, S.; Phuphuakrat, A. Saliva Sample as a Non-Invasive Specimen for the Diagnosis of Coronavirus disease 2019: A Cross-Sectional Study. Clin. Microbiol. Infect. 2020, 27, 285.e1-285.e4. [CrossRef]

38. Peng, L.; Liu, J.; Xu, W.; Luo, Q.; Chen, D.; Lei, Z.; Huang, Z.; Li, X.; Deng, K.; Lin, B.; et al. SARS-CoV-2 Can Be Detected in Urine, Blood, Anal Swabs, and Oropharyngeal Swabs Specimens. J. Med. Virol. 2020, 92, 1676-1680. [CrossRef]

39. Perchetti, G.A.; Nalla, A.K.; Huang, M.L.; Zhu, H.; Wei, Y.; Stensland, L.; Loprieno, M.A.; Jerome, K.R.; Greninger, A.L. Validation of SARS-CoV-2 Detection Across Multiple Specimen Types. J. Clin. Virol. 2020, 128, 104438. [CrossRef]

40. Rao, M.; Rashid, F.A.; Sabri, F.S.A.H.; Jamil, N.N.; Zain, R.; Hashim, R.; Amran, F.; Kok, H.T.; Samad, M.A.A.; Ahmad, N. Comparing Nasopharyngeal Swab and Early Morning Saliva for the Identification of Severe Acute Respiratory Syndrome Coronavirus 2 (SARS-CoV-2). Clin. Infect. Dis. 2021, 72, e352-e356. [CrossRef] [PubMed]

41. Senok, A.; Alsuwaidi, H.; Atrah, Y.; Al Ayedi, O.; Al Zahid, J.; Han, A.; Al Marzooqi, A.; Al Heialy, S.; Altrabulsi, B.; AbdelWareth, L.; et al. Saliva as an Alternative Specimen for Molecular COVID-19 Testing in Community Settings and Population-Based Screening. Infect. Drug Resist. 2020, 13, 3393-3399. [CrossRef]

42. Moreira, V.M.; Mascarenhas, P.; Botelho, J.; Mendes, J.J.; Taveira, N.; Almeida, M.G. Diagnosis of SARS-Cov-2 Infection by RT-PCR Using Specimens Other Than Naso- and Oropharyngeal Swabs: A Systematic Review and Meta-Analysis. Diagnostics 2021, 11, 363. [CrossRef] [PubMed]

43. Sahajpal, N.S.; Mondal, A.K.; Ananth, S.; Njau, A.; Ahluwalia, P.; Newnam, G.; Lozoya-Colinas, A.; Hud, N.V.; Kota, V.; Ross, T.M.; et al. SalivaSTAT: Direct-PCR and Pooling of Saliva Samples Collected in Healthcare and Community Setting for SARS-CoV-2 Mass Surveillance. Diagnostics 2021, 11, 904. [CrossRef]

44. Han, P.; Ivanovski, S. Saliva-Friend and Foe in the COVID-19 Outbreak Diagnostics. Diagnostics 2020, 10, 290. [CrossRef] [PubMed]

45. To, K.K.-W.; Tsang, O.T.-Y.; Yip, C.C.-Y.; Chan, K.H.; Wu, T.C.; Chan, J.M.-C.; Leung, W.S.; Chik, T.S.-H.; Choi, C.Y.-C.; Kandamby, D.H.; et al. Consistent Detection of 2019 Novel Coronavirus in Saliva. Clin. Infect. Dis. 2020, 71, 841-843. [CrossRef] [PubMed]

46. Azzi, L.; Carcano, G.; Gianfagna, F.; Grossi, P.; Gasperina, D.D.; Genoni, A.; Fasano, M.; Sessa, F.; Tettamanti, L.; Carinci, F.; et al. Saliva is a Reliable Tool to Detect SARS-CoV-2. J. Infect. 2020, 81, e45-e50. [CrossRef]

47. Meng, L.; Hua, F.; Bian, Z. Coronavirus Disease 2019 (COVID-19): Emerging and Future Challenges for Dental and Oral Medicine. J. Dent. Res. 2020, 99, 481-487. [CrossRef] [PubMed]

48. Peng, X.; Xu, X.; Li, Y.; Cheng, L.; Zhou, X.; Ren, B. Transmission Routes of 2019-nCoV and Controls in Dental Practice. Int. J. Oral Sci. 2020, 12, 9. [CrossRef] 